\title{
Analysis of Impact of the Transnational Corporations' R \& D Investment on Innovation Capability of the High-Tech Industry in Gansu Province
}

\author{
Jing $\mathrm{Xu}^{1}$ \\ ${ }^{1}$ School of Economics, Northwest University for Nationalities, Lanzhou, China \\ Correspondence: Jing Xu, School of Economics, Northwest University for Nationalities, Lanzhou 730124, China. \\ E-mail: 1037007123@qq.com
}

Received: April 28, 2014

Accepted: May 8, 2014

Online Published: May 13, 2014

doi:10.5430/ijba.v5n3p181

URL: http://dx.doi.org/10.5430/ijba.v5n3p181

This work was supported by the Fundamental Research Funds for the Central Universities of Northwest University for Nationalities (Grant No: 31920130098)

\begin{abstract}
The impact of the transnational corporations' $R$ \& D investment on innovation capability of the high-tech industry in Gansu Province is analyzed in this paper by the production function model in OLS regression analysis method from the view of the spillover effect and crowding effect. It is concluded that the spillover effect through competition is obvious while that through demonstration channels is not significant, and that the transnational corporations only invest a small amount in high-tech industry in Gansu Province so that the crowding effect is not significant.
\end{abstract}

Keywords: transnational corporations, R \& D investment, spillover effect, crowding effect

\section{Introduction}

Foreign direct investment (hereafter referred to as "FDI") plays a significant role in national and regional socio-economic development. The scholars study it from different views, including how to attract FDI, how to improve the utilization quality of FDI, the impact and function of FDI on national and regional economic development, adverse effects of imbalanced spatial distribution of FDI and so on. However, there are rare literatures about the research of the impact of transnational corporations' R \& D investment on the innovation capacity of the Chinese enterprises.

Gansu Province is China's geometric center and the western traffic fortress. Especially, the approval of national new area in Lanzhou City will attract more transnational investment in the future. The impact of the transnational corporations' R \& D investment on innovation capability of the high-tech industry in Gansu Province is analyzed in this paper.

\section{Overview of the Research Object}

Transnational corporations' $\mathrm{R} \& \mathrm{D}$ investment refers to the activity of the transnational corporations to set up branches or subsidiaries in the host country for research and development aiming at increasing the amount of knowledge and innovation. There are two main forms: one is the establishment of R \& D institutions abroad and the other is the implementation of international cooperation in research and development through the formation of transnational strategic alliances and other forms.

In this paper, the technical innovation capacity is reflected by spillover effect and crowding effect of transnational corporations' R \& D investment. The spillover effect and crowding effect of transnational corporations' R \& D investment refers to the promotion of the technical innovation and progress of the local enterprises in the host country by the R \& D activities of transnational corporations in the host country. However, the overseas R\&D of the transnational corporations may also block the technical innovation and progress of the local enterprises in the host country in some respects, which is called crowding effect. Spillover effect is mainly generated through demonstration, contact, flow of talents, competition and so on while crowding effect is mainly reflected by the crowding of independent innovation, human resources and research and development capital. Such two effects co-exist in the opposite direction. 


\section{Selection of Model}

\subsection{Spillover Effect Model}

In this paper, the spillover effect model is established based on Cobb-Douglas production function, and the specific variables are shown in Table 1.

Table 1. Setting of variables

\begin{tabular}{|c|c|c|c|}
\hline Variables & $\begin{array}{c}\text { Construction of } \\
\text { Variables }\end{array}$ & $\begin{array}{l}\text { Meanings of } \\
\text { Variables }\end{array}$ & $\begin{array}{l}\text { Forms of } \\
\text { Variables }\end{array}$ \\
\hline $\begin{array}{l}\text { Y (Dependent } \\
\text { variable) }\end{array}$ & $\begin{array}{l}\text { The number of patent } \\
\text { applications of } \\
\text { domestic-funded } \\
\text { high-tech enterprises }\end{array}$ & $\begin{array}{l}\text { Output of technical } \\
\text { innovation of the } \\
\text { local high-tech } \\
\text { enterprises }\end{array}$ & $\operatorname{Ln} Y$ \\
\hline $\begin{array}{l}\mathrm{X}_{1} \text { (Independent } \\
\text { variable) }\end{array}$ & $\begin{array}{l}\text { R \& D personnel } \\
\text { full-time equivalent of } \\
\text { three types of } \\
\text { foreign-funded } \\
\text { enterprises }\end{array}$ & $\begin{array}{l}\text { Talent flow effect of } \\
\text { transnational } \\
\text { corporations' R \& D } \\
\text { investment }\end{array}$ & $\operatorname{Ln}\left(X_{1}\right)$ \\
\hline $\begin{array}{c}\mathrm{X}_{2} \text { (Independent } \\
\text { variable) }\end{array}$ & $\begin{array}{c}\text { Internal R \& D } \\
\text { expenditure of three } \\
\text { types of foreign-funded } \\
\text { enterprises }\end{array}$ & $\begin{array}{l}\text { Demonstration } \\
\text { effect of } \\
\text { transnational } \\
\text { corporations' R \& D } \\
\text { investment }\end{array}$ & $\operatorname{Ln}\left(\mathrm{X}_{2}\right)$ \\
\hline $\begin{array}{c}\mathrm{X}_{3} \text { (Independent } \\
\text { variable) }\end{array}$ & $\begin{array}{l}\text { The number of patent } \\
\text { applications of three } \\
\text { types of foreign-funded } \\
\text { enterprises }\end{array}$ & $\begin{array}{l}\text { Competition effect } \\
\text { of transnational } \\
\text { corporations' R \& D } \\
\text { investment }\end{array}$ & $\operatorname{Ln}\left(\mathrm{x}_{3}\right)$ \\
\hline $\begin{array}{l}\mathrm{X}_{4} \text { (Independent } \\
\text { variable) }\end{array}$ & $\begin{array}{c}\text { Internal R \& D } \\
\text { expenditure of } \\
\text { domestic-funded } \\
\text { high-tech enterprises }\end{array}$ & $\begin{array}{c}\text { Demonstration } \\
\text { effect of local } \\
\text { corporations' R \& D } \\
\text { investment }\end{array}$ & $\operatorname{Ln}\left(\mathrm{X}_{4}\right)$ \\
\hline $\begin{array}{c}\mathrm{X}_{5} \text { (Independent } \\
\text { variable) }\end{array}$ & $\begin{array}{l}\text { R \& D personnel } \\
\text { full-time equivalent of } \\
\text { domestic-funded } \\
\text { high-tech enterprises }\end{array}$ & $\begin{array}{l}\text { Competition effect } \\
\text { of local } \\
\text { corporations' R \& D } \\
\text { investment }\end{array}$ & $\operatorname{Ln}\left(x_{5}\right)$ \\
\hline
\end{tabular}

Modeling, wherein $\varepsilon$ is the error item:

$$
\begin{aligned}
& \operatorname{Ln} Y=\beta_{0}+\beta_{1} \operatorname{Ln}\left(X_{1}\right)+\beta_{2} \operatorname{Ln}\left(X_{2}\right)+\beta_{3} \operatorname{Ln}\left(X_{3}\right) \\
& +\beta_{4} \operatorname{Ln}\left(X_{4}\right)+\beta_{5} \operatorname{Ln}\left(X_{5}\right)+\varepsilon
\end{aligned}
$$

\subsection{Crowding Effect}

It is difficult to quantify crowding effect. Thus, three groups of existence tests are performed on the crowding effect of the transnational corporations' R\&D investment from three aspects of the crowding effect in this paper. 
1) Self-innovation crowding effect

The dependence indicator can be used to measure the crowding effect of transnational corporations' R \& D investment on the innovation capability of high-tech industry, specifically by making use of foreign-trade dependence indicator.

$\mathrm{R} \& \mathrm{D}$ investment dependence $=\mathrm{R} \& \mathrm{D}$ investment of three types of foreign-funded enterprises in current year/total output value of the industry in current year.

2) Human resources crowding effect

Assuming that the researchers can only work in three types of foreign-funded enterprises and domestic-funded enterprises, the change trend can be analyzed according to the proportion of transnational corporations' R \& D staff full-time equivalent accounting for the R \& D staff full-time equivalent of high-tech industry to verify whether there is crowding of human resources.

Staff proportion= transnational corporations' R \& D staff full-time equivalent/ R \& D staff full-time equivalent of high-tech industry in Gansu Province.

3) R \& D capital crowding

The growth trend in transnational corporations' R \& D investment and R \& D investment of high-tech enterprises can be compared to analyze whether there is R \& D capital crowding.

\section{Empirical Analysis}

\subsection{Spillover Effect Analysis}

Sample data is from the China Statistics Yearbook on High Technology Industry, China Statistical Yearbook on Science and Technology and Yearbook on Science and Technology of Gansu Province. Eviews6.0 software is used for analysis.

First, the correlation of the variables in Table 1 is validated and the results are shown in Table 2.

Table 2. Correlation analysis

\begin{tabular}{llllll}
\hline \multicolumn{7}{c}{ Correlation } & & & \\
& LOG(X1) & LOG(X2) & LOG(X3) & LOG(X4) & LOG(X5) \\
\hline LOG(Y) & -0.45209 & -0.33028 & 0.864964 & 0.943124 & 0.716478 \\
\hline
\end{tabular}

It can be seen that there is a negative correlation among $\operatorname{Ln}(\mathrm{x} 1), \operatorname{Ln}(\mathrm{x} 2)$ and $\operatorname{Ln}(\mathrm{Y})$, but the correlation is not significant, indicating that the role of talent flow effect and demonstration effect is not significant and there is no spillover effect. There is a positive correlation among $\operatorname{Ln}(\mathrm{x} 3), \operatorname{Ln}(\mathrm{x} 4)$ and $\operatorname{Ln}(\mathrm{Y})$, and the correlation is significant. The correlation between $\operatorname{Ln}(x 5)$ and $\operatorname{Ln}(Y)$ is not significant, indicating that spillover effect generated by the competition is significant. In the following regression analysis, non-significant variables are excluded and regression analysis is made only into $\operatorname{Ln}(\mathrm{Y}), \operatorname{Ln}(\mathrm{x} 3)$ and $\operatorname{Ln}(\mathrm{x} 4)$. The regression equation is obtained by Eviews software:

$$
\operatorname{Ln} Y=0.9325 \operatorname{Ln}\left(X_{3}\right)+0.6446 \operatorname{Ln}\left(X_{4}\right)-3.8883
$$

$\mathrm{R}^{2}=0.99$, the adjusted $\mathrm{R}^{2}=0.97, \mathrm{~F}=55.43, \mathrm{DW}=2.00$.

The model is of good fitting degree, with significant $\mathrm{F}$ value. It can be seen that the demonstration effect of local enterprises' R \& D investment and competition effect of transnational corporations' $R$ \& D investment have great positive impact on technical innovation output. In case that the internal R \& D expenditure of domestic high-tech enterprises increases by $1 \%$, the number of patent applications of the high-tech industry in Gansu Province will increase by $0.64 \%$. Spillover effect of transnational $\mathrm{R} \& \mathrm{D}$ investment through competition is more significant. In case that the number of patent applications of three types of foreign-funded enterprises increases by $1 \%$, the number of patent applications of the high-tech industry in Gansu Province will increase by $0.93 \%$. 


\subsection{Crowding Effect Analysis}

1) Self-innovation crowding

In light of incomplete R\& D investment data and small amount of investment of three types of foreign-funded enterprises in high-tech industry in Gansu Province that year and the poor analysis results, R\& D investment of three types of foreign-funded enterprises in industrial enterprises in Gansu Province in that year is used hereby so that analysis conclusion will suffer amplified error.

The relevant data is put into the formula (2). The calculation results show stable but small R\&D dependence indicator, fluctuating substantially around four. (Note 1) This is mainly because of the small total R \& D investment of transnational corporations in Gansu Province so that the local high-tech industries mainly rely on local investment or industrial transfer from the eastern region of China, with minor dependence on transnational corporations' R \& D investment. In addition, the $2010 \mathrm{R} \& \mathrm{D}$ dependence was abnormal, namely 45.36. Due to the absence of sufficient information, the cause is failed to be found. In summary, R \& D investment has no significant crowding effect on high-tech enterprises in Gansu Province.

2) Human resources crowding effect

In light of the lack of the high-tech industry transnational corporations' R \& D staff full-time equivalent, analysis is made according to the proportion of transnational corporations' R \& D staff full-time equivalent accounting for the $\mathrm{R}$ $\&$ D staff full-time equivalent of industrial enterprises in Gansu Province. Equation (3) is changed into equation (4):

Staff proportion= transnational corporations' R \& D staff full-time equivalent/ R \& D staff full-time equivalent of industrial enterprises in Gansu Province (4)

The relevant data is put into the formula (3) and (4) to obtain Figure 1:
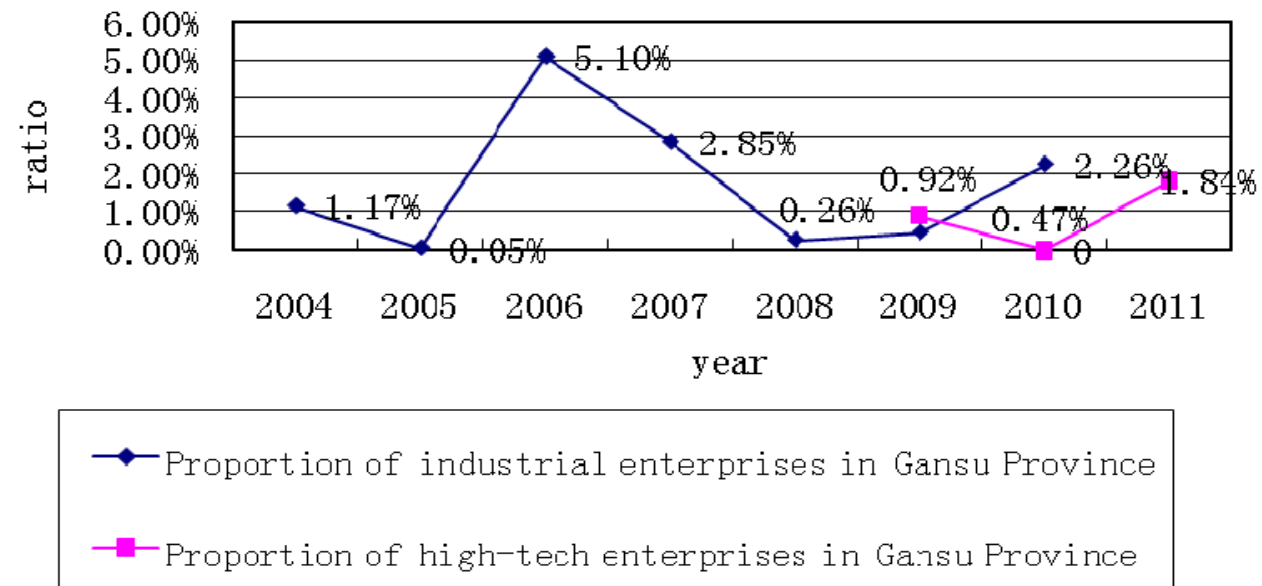

Figure 1. Comparison of proportion of R \& D personnel in high-tech enterprises and industrial enterprises in Gansu Province

It can be seen that in recent years transnational corporations' $\mathrm{R} \& \mathrm{D}$ personnel have accounted for a small proportion, wherein the proportion of R \& D personnel in industrial enterprises and in high-tech enterprises in Gansu Province has no obvious rules, fluctuating significantly, which to a certain extent indicates that the human resources crowding effect of transnational corporations' R \& D investment is uncertain. In addition, compared with 2009, high-tech enterprises in Gansu Province increased in 2011, indicating generation of crowding effect but it was not obvious. In 2010 , the value was zero, indicating that in that year there was no or few transnational corporations' R\&D personnel developing R\&D activities in high-tech industry in Gansu Province.

3) R \& D capital crowding

The relevant statistical data in recent years is sorted to get Table 3 . 
Table 3. Comparison of R \& D investment of transnational corporations and high-tech enterprises in Gansu Province

\begin{tabular}{ccc}
\hline Year & $\begin{array}{c}\text { R \& D } \\
\text { investment of } \\
\text { transnational } \\
\text { corporations in } \\
\text { Gansu Province }\end{array}$ & $\begin{array}{c}\text { R \& D investment } \\
\text { of high-tech } \\
\text { industry in Gansu } \\
\text { Province }\end{array}$ \\
\hline 2007 & 5315 & 3323 \\
\hline 2008 & 344.5 & 10021 \\
\hline 2009 & 183 & 12117 \\
\hline 2010 & 3670 & 30314 \\
\hline 2011 & 376 & 23901 \\
\hline
\end{tabular}

As can be seen from Table 3, the growth trend of transnational corporations' R \& D investment and that of high-tech enterprises' R\&D investment in Gansu Province is contrary so that there is crowding of research capital. During 2011 and 2012, both grew in the same direction so that there was no crowding effect. Thus, the growth of high-tech enterprises' R \& D investment in Gansu Province was not significantly affected by transnational corporations' R \& D investment. It may be due to the small amount of transnational corporations' $R$ \& D investment in Gansu Province so that its role can not be reflected. On the other hand, in case of good political and economic environment, R \& D capital crowding effect can also be changed into spillover effect.

\section{Conclusion}

The impact of the transnational corporations' $\mathrm{R} \& \mathrm{D}$ investment on innovation capability of the high-tech industry in Gansu Province is analyzed in this paper from the view of the spillover effect and crowding effect. It is concluded that the spillover effect through competition is obvious. Talent flow and demonstration nearly has no spillover effect but even had crowding effect. Transnational corporations' R \& D investment has no significant crowding effect on self-innovation, human resources and R\&D capital of high-tech enterprises in Gansu Province, wherein is the main reason is the small $R \& D$ investment amount from transnational corporations in high-tech industry in Gansu Province so that it is insufficient to reflect crowding effect. In addition, since data is not available, regression analysis is made only into the "number of patent applications" on "technical innovation output" but not into the "revenue from sale of new products" on "technical innovation output" in this paper, which will affect the regression analysis conclusions to a certain extent.

\section{References}

Dunning, J. (1994). Multinational Enterprises and the Globalisation of Innovatory Capacity. Research Policy.

Hu, Zuliu. (2004). Three Important Issues in China' Utilization of FDI. International Economic Review, (2).

Li, Jun. (2008). Research of Influence and Effects of Transnational Corporations' R \& D in China. East China Normal University.

Pan, Jing, \& Zhang, Jiarong. (2012). The Empirical Study on the Influence of Multinational Corporations' R \& D Investment on China's High-tech Industry Innovation Ability. Forum on Science and Technology in China, (1).

Pearce R. D. (1987). The Internationalization of Research and Development by Multinational Enterprises. New York: St. Martin Press.

Ping, Xinqiao. (2007). Analysis of the Spillover Effect of Foreign Direct Investment on Chinese Enterprises: Report from China's First National Economic Census Data. The Journal of World Economy, 10.

Zhang, Haiyang, \& Liu, Haiyun. (2004). Effect of FDI Spillover Effect and Competition Effect on China's Industrial Sector. Journal of International Trade, (3).

\section{Note}

Note 1. Since the dependence indicator calculation value is small, the calculation result is multiplied by 10,000 for easy analysis. 